\title{
NEWBERRY
}

NOTE ON THE GEOLOGY AND BOTANY OF THE COUNTRY BORDERING

\author{
THE NORTHERN \\ PACIFIC RALLROAD
}


The Bancroft Library

University of California - Berkeley 
at

(1)

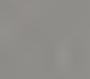


T

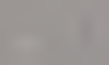

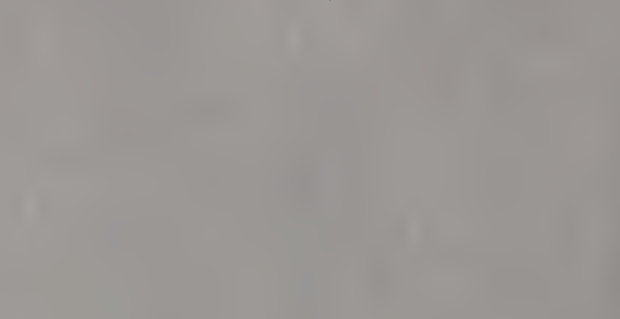

$+2$

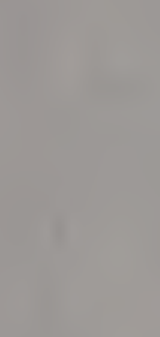

-

$$
\sqrt{2}+\frac{1}{2}
$$

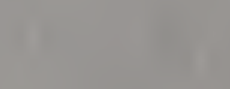


Digitized by the Internet Archive in 2007 with funding from Microsoft Corporation 


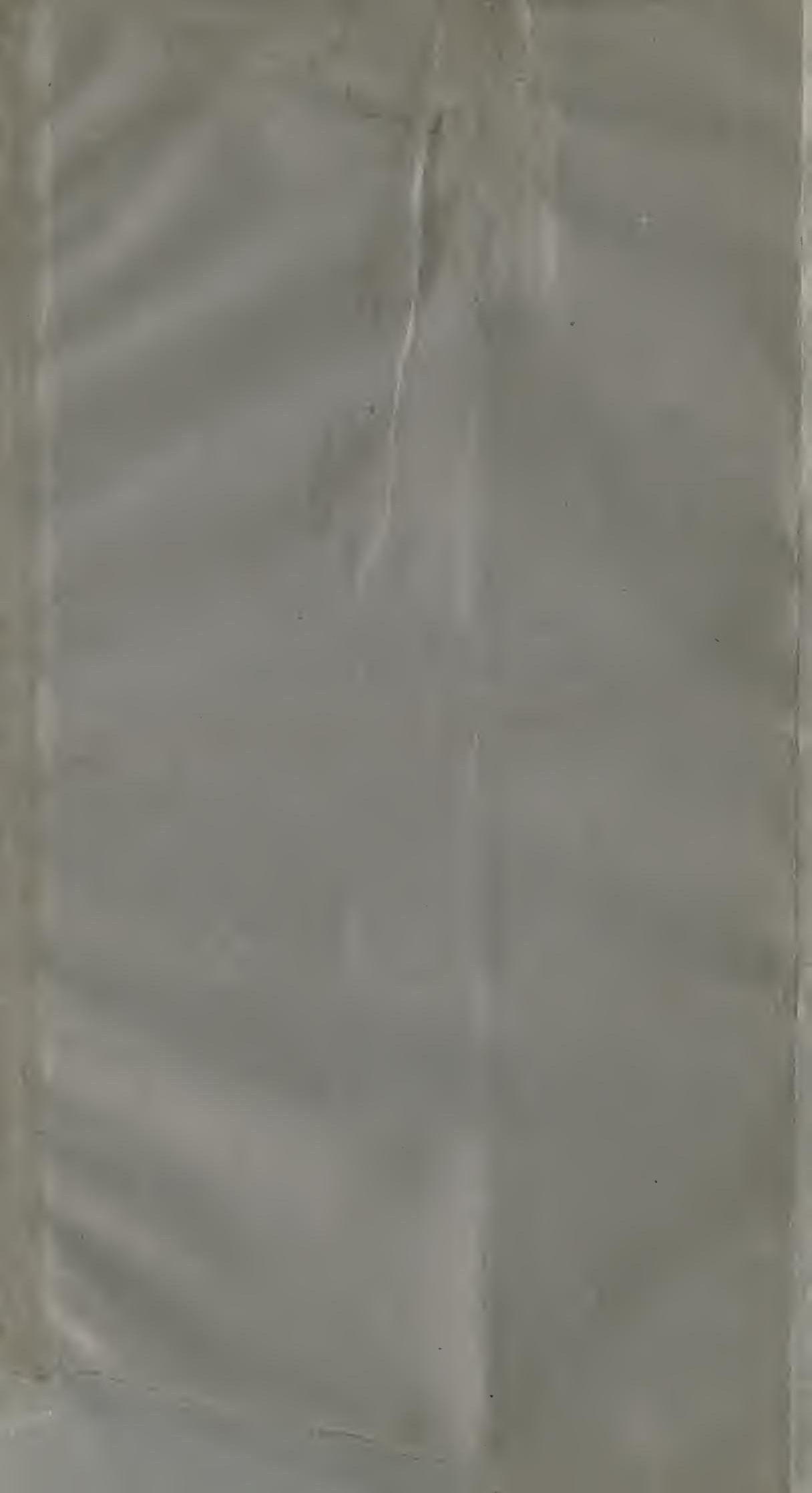




\section{NOTES ON THE}

\section{Geology and Botany}

OF 'THE COUNTRY BORIDERING 'THE

\section{NORTHERN PACIFIC RAILROAD,}

PROF. J. S. NEIIBERRY.

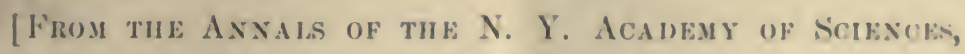
Vol. III, No. 8, 1854.] 



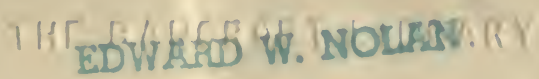

Geology and Botuny of Northern Parific Railroad.

$24 \%$

XI. - Notes on the Geology and Botany of the Country bordering
the Northern Pacific Railroad.

BY J. S. NEWBERRY.

Read February 4th, 1884.

Having been several times over the line of the Northern Pacifio R. R., and through the comntry bordering the lower Columbia and Puget's 'Sound, and having found some things that were of interest to me, I venture to offer a few notes npon thein to the members of the Academy.

Going west from Dulnth to Brainerd, the line of the road for the most purt lies in what is evidently the old deserted bed of a wrstward extension of Lake Superior. The ground is still low and swampy, and much of the surface is formed of what is $\mathrm{nn}$. mistakably lake sand.

From Chicago through Wisconsin and Minnesota, the road passes over an almost unbroken sheet of drift, which though of great interest, has been so fully illnstrated. in the able reports of Messrs. Chamberlin, Winchell and Upham, that nothing further need be said here in regard to it. At various points the true till is seen, with its striated pebhles: and one such exposure is within reach of every traveler, at Audubon. Beyoud this, the boulders are seattered over the surface. and pebbles in the ditches continue as evidence of the transport of material from the eastern highlands. About Bismarek the boulders, though fewer, are still not rare, and are gathered in groups, as elsewhere along the margin of the drift area, constituting a kind of fringe, and suggesting their transport by ice flouts. The last of these bonlders is seen at Sims, abont 20 miles from Bismarck. From this point to the crossing of the Little Missouri, one could hardly find a stone to throw at a bird, or a shrnb big enough to make at tooth-pick. This region is an extension northward of that broader prairie area which I have crossed in many places further 
south. Here, between the eastern drift and that from the Rocky Mountains, the soil is formed entirely by the decomposition of the underlying rocks; and wherever these are shales and calcareons sandstones, as they are thronghout most of the Creticeous formation, there are no outcropping ledges of rock, the country is smooth, and stone of all kinds is scarce.

This belt, which runs from the Mexican to the Canadian line, is prairie because of the dryness of the climate, and not on account of the geological substructure ; for, between the "Crosstimbers" and the Raton Mountains, with a great variety of geology and topography, there are no trees except along the watercourses; which, fed by the melting of the snow on the Rucky Mountains, are perennial, and supply constantly the amount of moisture that is a necessity for tree growtl. The peculiar fineness of the soil of the northern portion of this belt has been supposed to have something to do with the preralence of grass and the absence of trees; since in Illinois and Wisconsin, along the border line between the forest area and the prairie, the levels where the soil is fine are,grass-covered, while the swells and ridges, rocky or gravelly, carry trees; but as I have shown elsewhere, these local peculiarities of the soil, faroring, the first grass and the second trees, have simply caused the interlocking of prairic and forest along the debatable line.

Further west, with every kind of soil, geological structnre and topography, there are no trees, but everywhere grass ; while east of the Mississippi and beyond the battle-ground between the two forms of vegetation, all kinds of topography, soil and geological substructure are corered with forest. No one who has traversed the continent, as I liave done, along several parallels of latitude, and has studied the relations of vegetation to soil and geological structure, will fail to find conclusive evidence that the influence which has determined the kind and quantity of regetation in the varied topographic and climatic districts of the West, is the rainfall.

The valley of the Little Missouri is deeply cut in a table-land composed of the Laramie coal-measures, of which 200 or 300 feet are exposed in the cliffs, with several seams of coal. Thousands of silicified tree-trunks lie scattered orer the surface, and inuu. merable stumps are standing apparently where they grew ; but no foreign material is anywhere visible. 
A few miles below the railroad crossing. the valley expands and oprons into the famous muncaives terres, or "bad lands of the Missmri." 'The comse of that stremm is here nearly enst and west : and the valleys of the tributaries ruming north and south, coulesce, and form in the old liske-bed a picturesque lut danger(1IIs labyrinth.

As soon as one enters the ralley of the Vellowstone. he finds limself surrounded by transpored material. Gravel and hould. ers of crystalline. sedimentary and rolcanic rocks form the ber and bars of the river, increasing in conseness and quantity all the way to livingston: but in all this material I was unable to find anything that was to me eren presumalyly of enstern origin. 1)r. C. A. White. (Am. Journal of Sci., vol. XXV, 1883, p. 206, ) reports finding what he considers eastern glacial drift along the alley of the Missouri and that of the Yellowstone; but $\mathrm{my}$ search for such material was vain. As will be seen further on. I found in the valley of the Missonri about the Falls. great quantities of drift with houlders of fossiliferous limestone, quartrite, gmeiss and granite, all remarkably like the Eastern drift. but which I subsequently traced to their places of origin in the Belt Mountains.

The surface geology of the Yellowstone Park has been described in considerable detail by $\mathrm{Mr}$. W. H. Holmes and Mr. A. C. Peale: but I was surprised to find the traces of glacial action so wide-spread and unmistakab.e. It is probably not tou much to say that every valley of the Park was once filled with ice; for moraines, boulders, glacial lakes, and more rarely glacial stria, give testimun that cannot be disputed. Ice-borne blucks are seen on the sides of the Yellowstonc valley, below the moutl of Gardner's River : and abont Mammoth Ilot Springs, (xery depression once held a glacier. Swan lake is of glacial origin, and is bounded on the south by a moraine, while lateral moraines and striated rock-surfaces mark the old ice-level high up on the sides of the valley. Near Marshall's, the road leads over a succession of great moraines of clay and bublders, which continue to and around the Fire Hole basin. and prove that this also was ouce largely filled with ice. From all that I conld learn, the evidences of glacial action, found here in the lowest portion of the Park, may be traced through all parts of it. 
Between Livingston and Bozeman, the railroad passes over a spur of the Rocky Mountains composed chiefly of Palæozoic limestones, part of which are Carboniferous. Above these are red beds which probably represent the Jurassic and Triassic, and still higher Laramie rocks with coal, apparently the same section exposed in Cinnabar Mountain, in the valley of the Yellowstone just north of the Park. 'The strata are very much disturbed, the coal much crushed and twisted, so that it works small, but it is extensively mined for use on and along the railroad, and is esteemed a good fuel. Fossil plants associated with the coal. prove it to be of the same age with that exposed in the cliffs at the crossing of the Little Missouri. One feature of the Bozeman coal it has in common with some of that from much disturbed beds in Washington Territory and Colorado. It contains a large quantity of yellow, translucent amber-like resin, in seams and patches. As this occurs in the joints of the coal, it is evidently a secondary product resulting from its partial distillation.

\section{DRIFT OF THE UPPER Missouri.}

The Missouri River, formed by the union of the Madison, the Gallatin and the Jefferson, at Gallatin City, traverses with is north-westerly and then northerly course, the ralley between the Rocky and Belt Mountains, and finds its way ont to the plains by a long circuit around the northern bases of the Belt and Crazy Mountains, which belong to the Rocky Mountain system, and constitute their eastern outliers. Cutting through harriers formed by low interlocking spurs, at the "Gate of th" Mountains," the river enters an undulating prairie country which extends from the north side of the Belt Mountains to and beyond the Canadian line. All this region is occupied by a sheet of drift that in thickness and extent rivals that of the plains surrounding the Canadian highlands; but as far my observation extended I found this to be of local origin.

At the Great Falls of the Missouri, the underlying rock is fully exposed, but the drift sheet comes up to the edge of the gorge and forms the low hills which stretch away to the east and north like the long swells of the ocean. In the valleys of the streams which come down to the Missouri from the Belt Moun- 
tains, the rock substructure is visible; but the intervening plateaus are covered with a sheet of drift clay and boulders, that varies greatly in thickness, as it is spread over a rock-sur. face that was once deeply and irregularly eroded. For example, near the Upper Falls of the Missouri, where the banks of the river are perhaps a hundred feet high, of solid rock, a tributary coming in from the south cuts across an old valley filled with drift which extends almost to the present river channel. At its month, this tributary has high rocky banks; but a few hundred yards above, they are altogether composed of drift. 'This drift is a true till, thickly set with boulders, some of which are two feet or more in diameter. They are usually rounded, sometimes subangular, and are composed of gray or red granite, quartzite. palæozoic limestone, and a variety of eruptive rocks. The resemblance of this drift to that from the Canadian highlands, is so great that I was only convinced of its local origin when I found all of its constituents in place in the Belt and Rocky Mountains. The granites were to my eye indistinguishable from those of the eastern Laurentian series; they are of Archran age, as I subsequently learned ; and nothing but careful microscopic examination will show them to be distinguishable, if they are so. These facts lead me to suspect that even the very careful and experienced observers who have reported the finding of eastern Laurentian boulders on the flanks of the Rocky Mountains, 4,000 feet above the sea, may have been misled by this striking resemblance.

On the undnlating surface of the table-lands between the tributaries of the Missouri, large boulders are uccasionally seen, as in the States bordering the Great Lakes ; and one of these, somewhat angular in form, has served so long as a rubbing-post for the buffialoes which recently abounded in that region, that its sides are all polished and a deep furrow is worn uround it.

Immediately south of the Falls of the Missonri, an extensive coal-basin of Cretaceous (?) age is opened by the valleys of the streams which come down from the Belt and Highwood Mount. ains. 'Two coal seams are exposed, one thin, the other from 1: to 18 feot in thickness, the latter a compound seam, some of the benches of which are bright, pure coking coal.

The Falls of the Missouri, caused by beds of sandstones belong. 
ing to this coal formation, consist of a series of cascades having an aggregate height of over 200 feet; the lower fall is 98 feet, the next 25 , the next 40 , the next 20 , etc. They occupy the whole breadth of the river, which is here about 1500 feet; and as the volume of water is large, they are exceedingly beautiful and also furnish a water-power rivalling in magnitude that of Niagara, and far more available.

\section{Geology of the Belt Mountains.}

The streams which flow into the Missouri from the Crazy and Belt Mountains, form valleys which are remarkably picturesque and of great geolugical interest. 'The coal-basin to which I have referred is underlain by palæozoic limestones more thin two thousand feet thick. These rise toward the south, where they rest upon the Cambrian and Archæan nucleus of the mountains. Deeply cut by the draining streams, they form the walls of a series of narrow valleys or cañons, which, though less impressive in magnitude, are more beautiful than those of the Colorado. The limestones are sometimes blıe, more generally cream-colored, and lie in massive beds of 100 to 200 feet in thickness; these form a series of steps in the precipitous walls of the valleys, from which project spires, castles, fortifications, and other colossal imitations of human architecture. 'The light cream tint of the prevailing limestone contrasts charmingly with the dark green of the fir-trees that crown the summits and cluster in picturesque groups wherever they can find a foothold on the declivity. Add to these elements a variety of minor plants, which with varied colors decorate the cliffs, and the whole forms a combination which in beauty surpasses anything that I have elsewhere seen in somewhat extended wanderings through the far West.

Cutting through the limestones and in places the coal-bearing rocks, are eruptive dykes of three distinct kinds, which Mr. J. P. Iddings has been kind enough to examine for me microscopically. He repurts them to be, first, a typical augite-andesyte, which forms the Bird 'Tail Divide and the upper portion of "Square Butte," a conspicuous landmark on the west side of the Missouri ; second, a true trachyte, with large crystals of feldspar, 
much like that of the Irachenfels, at the head of Belt Creek : and third, a rhyolite, on the summit of Little Belt Momntain.

At Neihart, the centre of the Archatun nucleus of the Lintle Belt Mountains is reached. 'The prevailing granite is reddish and somewhat banded with brown and green, and thongh very massive is indistinctly bedded and apparently metamorphic. It is cut by enormous dykes of a very coarse and mottled granite, consisting of obscurely rounded masses of feldspar separated by hornblende and black mica. These granile rocks are traversed by a great number of fissure-reins, generally with vein-stones of quartz, heavy spar, and oxide of manganese, and carrying snlphides of silver and lead; the ores are rich but the reins small.

On the south side of the valley at. Neihart the cliffs of granite. 1200 feet in height, are corered with a sheet of Potsdam sand. stune several hundred feet in thickness, the contact being visible for miles. 'The sandstone is red, generally soft, but sometimes a coarse and hard conglomerate. It here contains no fossils, but is full of annelid borings (Scolithus), and las the aspect-as it has the geological relations-of the Potsdam in the Black Hills and in the Adirondacks. On the sumnit of the nountain, some of the npper beds of sandstone are filled with, and largely composed of, primordial trilobites.

The eridences of former glacial action in the Belt Mountains are abundant but are not of a striking character. 'They consist of beds of boulder clay, and in some of the higher valleys, of roches moutonnées or smoothly planed surfaces. Gla. cial stria were not observed, having been obliterated by weathering.

All the upper portion of the Belt Mountuins is covered with a dense forest composed of Douglas's and Engelmann's spruces, Abies Douglasii, and A. Engelmanni, the balsam fir. Abies concolor, and Pinus contorta. In places, the trees are hearily draped with tufts and streamers of the jet-black fibres of Alectoria sarmentosa; while many trees and particnlarly dry branches are decorated with bunches of the lemon-yellow Erernia vulpina. Lower down on the mountain are scattered trees of Pinus ponderosa.

'The valley of Smith's River separntes the Great Belt from the Iittle Belt Mountains. It is as picturesque and beuntiful as the 
valleys on the north side of the mountains, but is quite different in aspect. The sides generally are smooth and unbroken slopes, 1500 feet or more in height, covered with rich grass and presenting no rock exposures. The summits of the hills are erowned with erergreens which here and there creep down the ravines, of which they occupy, in preference, the slopes having a northern exposure, because here the snow lies deepest and longest, supplying the greatest amount of moisture. 'The cause of the peculiar topography of the villey of Smith's River is to be found in its geological substructure, for it is cut all the way to Sulphur Springs, in Cambrian rocks, which form a series several thousand feet in thickness. They are mostly argillaceous shales or slates, which break down together and form gentle slopes.

Sulphur Springs is a well-built, handsome town, of sercral thousand inhabitants, gathered around hot springs which have a high reputation for their medicinal properties. From Sulphnr Springs we crossed the sonthern extension of the Great Belt Mountains to the valley of the Missouri at Townsend. The range is here altogether composed of the Cambrian (?) slates which form the banks of Smitl River,-probably the same seric's that is cut by the somewhat famous and picturesque Prickly Pear Cañon on the west side of the Missouri. In some places these slates are compacted by local metamorphism into masses of considerable hardness, but generally they are rather soft, fine grained argillo-silicious rocks, blue or gray in color, and finely laminated by planes of deposition. Occasionally a harder layer, an inch or two in thickness, is more silicious and rings like novaculite. These rocks have suffered no change which would obliterate fossils, and look as promising as any shales; but the most careful search failed to detect a single fossil in them, although specks of carbonaceous matter were often scen, and some shadowy outlines that suggest sei-weeds. There is little donbt that this is the sume formation with that seen beneath the Potsdam in Little Cottonwood Cañon near Salt Lake City, and in the Cañon of the Colorado, - a formation considered Cambrian by King, Powell and Walcott, and which has yielded the latter a few fossils, but is universally barren and disappointing. It does not occur between the Potsdam sandstone and the granite in the Belt Mountains, for the same reason that the "Georgia 
slates" do not underlie the Putsdam in the Adirondacks, vi\%.. because the Potsdam is a sheet of sea-hench, produced by a wiclespread, almost continental, depression of the land, or gencral cele. vation of the seatevel, which carried the shore-line inland beyond the areas where the Cambrian rocks had accnumbated.

The valley of the Missouri about Gallatin, and for unarly 100 miles below, is very broad and fertile, and is generully occupied by farmers or stock-ruisers. Wheat, rye, and especially oats are successfully cultivated, but mainly by irrigation. All the low. lands and the foothills of the mountains are covered with a tine growth of bunch.grass, blue-stem and grama, upon which cattle, sheep and horses are well sustained throughout the year. The winters are long and severe, but not more so than in Minnesota, and the snow-fall is somewhat less. The stock is not gencrally fed or housed, though it would be more merciful and probably more economical to provide some shelter.

\section{'THE Rocky Mountars.}

Helena, the capital of Montana, is a well-built and wealehy town of some 8.000 inhabitants, loeated in and about the mouth of Last Chance Gulch, one of the famous gold-camps in the time of placer mining.

'The foot-hills of the first range of the Rocky Mountuins, here and northward to the British line, are composed of the palaeozoic rocks which surround the Belt Mountains. About Helena, they are generally limestones, somewhat metamorphosed, but not much broken up. The rarious ravines which lead to the Missouri valley, head in the granite rocks of the core of the rarge; and near these, the palaomic series is very much disturbed. 'The granites, as well as some of the sedimentary rocks, are traversed by many mineral veins, some of which are auriferous and have furnisher the large amount of gold that has been taken from the gulches. Most of the mineral veins are, however, silver-bearing, and these form a number of groups where there are, or will herenfter be, prosprerous mining camps. At Wickes, twenty miles south of Helena, are numerous mines now success ully worked, and a rery exteusive plant for the concentration and trentment of the ores by smelting and leach. 
ing. A branch of the N. P. R. R. runs up to Wickes, carrying coke and other supplies at so cheap a rate as to give success to enterprises which were before unprofitible. The ores worked are argentiferous galena, containing much blende and pyrites.

The limestone series in this valley is underlain by heary beds of quartzite, which apparently represent the Potsdam sandstone.

Red Mountain, sixteen miles west of Helena, lies at the head of another valley similar to that at Wickes; but the quartzites are here less conspicuous; the limestones only becoming silicious and flinty at their base. Red Mountain is cut by an immense number of mineral veins, generally of small size,-from one to six feet in thickness, - but exhibiting a remarkable uniformity in direction and mineral characters. They are approximately parallel, apparently continuous throngh the mountain, stand nearly vertical, and carry argentiferous galena, gray copper, zinc-blende and pyrites. 'The veinstone is chiefly quartz, but in some places consists almost entirely of black hornblende. 'The ores generally carry from 25 to 100 onnces of silver, but the gray copper, which is the richest, contains from 200 to 2,000 ounces per ton. Systematic mining operations are just beginning here; and should a branch road be carried up to the mines, it would seem that they must be productive and profitable.

After passing Helena, the line of the Pacific Railroad soon turns into the mountains and crosses the first or main range, coming down on to the head waters of Clark's Fork and entering a broad and fertile valley, which has its chief center of population at Missoula. The western border of this valley is formed by the Bitter Root Mountains, part of the broad belt made up of the western ranges of the Rocky Mountain system. All these consist of granite, broken through in many places by eruptive rocks, and flanked by quartzites, slates and limestones, which probably represent the Cambrian, Silurian and Carboniferous systems. In the lowlands which lie between the ranges, there are basins of quite mordern Tertiary rocks.

A few miles below Missoula the road crosses a series of deep ravines, spanned by bridges, one of which is 211 feet in height. The rock exposed here is all slate of Archæan or Cam- 
brian age. Below this, the road closely follows the conrse of Clark's Fork, through one of the most picturesque valleys on the continent. The immediate banks of the river are often precipi. tous masses of limestone, above which the wooded mommtains rise to the height of 3000 or 4000 feet. 'T'he conrse of the railroad is northwest, until it approaches within tifty miles if the British line. 'This great deflection is cansed by the westorn ranges of the Rocky Mountains which are high and contiunous until the vicinity of Pend Oreille Iake is reached. Here they fall off, and the roal turns directly west through them. The lake is an irregular sheet of water, crescent-shapod and fifty miles in length ; set with numerous islands and surromeded with mountains, it is extremely picturesque. 'I'he mountains consist of granite, flanked by slate, quartzite and limestone, all much metamorphosed, but apparently the palaozonic series which is seen holding the same relation to the granite in so many places in Idaho and Montana.

'The western range of the Rocky Mountains, like the eastern, is metalliferous, but to what degree is hardly known, because most of it is yet unexplored. Veins of argentiferous galena and aturiferous quartz have been found in the vicinity of Pend Oreille Lake, and the already famous but greatly orer-rated Cour d'Alene mines lie a few miles south of the line of the road.

\section{Forests of the Rocky Mocntals.}

The forest regetation of the Rocky Mountains and the ralley of Clark's Fork, is abmndant and interesting. Abont Helena. are seen the trees which are characteristic of the Park and all the eastern flank of the Rocky Momntains. The round leaved cottonwood, Populus monilifera, with willows, the buffulo-berry, Shepardia argentea, etc., flomrish along the rivers: Pinus ponderosa and Douglas's spruce in the foot hills; on the monntain-sides, the narrow-leaved poplar and the aspen, (Populus angustifolin and P.tremuloides) Engelmann's spruce and the western balsam tir ; and Pinus contorta and Pinus flexilis on the monutain sum. mits.

Immediately after passing the divide, however, the character. istic elements of the Pacific coast vegetation begin to make their 
appearance. Douglas's spruce becomes more abundant, and the trees grow larger, evidently feeling more at home, while the western larch (Larix occidentalis), the western arbor vitæ (Thuja gigantea), the western hemlock (Tsuga mertensiana), and Pinus monticola, never seen on the east side of the mountains, multiply until they constitute the greater part of the forest. The upper Columbia is the special home of the western larch and the mountain pine, though they extend westward to and on to the Cascade Mountains; but about the mouth of Clark's Fork they often constitute half the forest. The western hemlock begins here with small trees, which have the aspect and indeed all the characters of its eastern representative, of which it is in fact only a variety. In the moist and equable climate of the lower Columbia it acquires the greater size, smoother bark and more fine-grained wood, which are its distinguishing characters.

The interval between the Rocky Mountains and the Cascades is quite different in its topography, geological structure and vegetation from any region east of it. It is generally destitute of trees, though a few scattered yellow pines reach out from the Rocky Mountains on the one side and the Cascales on the other, along this line, and though not numerous grow to a large size.*

In a general way this is a plain, but the monotony of the surface is broken by a great number of low hills and knobs of black or brown basilt, the product of the ro!eanic eruptions by which the plain has been repeatedly flooded in Tertiary and

* Further south this arid belt is the special home of this tree. One hundred miles south from the Columbia River, it forms continuous forests where the trees, rooted in the light volcanic soil, closely set, are often four, five or six feet in diameter. In these forests there is no other tree and scarce any undergrowth. Here and there a clump of Cercocarpus or red gooseberry is seen. The ground is usually bare, and so soft that horses sink into it to the fetlocks. The absence of animal life is also striking : one may travel through this forest an entire day and scarce hear the chirp of a bird or the hum of an insect ; and yet the yellow pine is there in its glory. its huge, cylindrical trunk covered with large plates of cinnamon-colored bark, standing as they have done for ages waiting the advent of their insatiable enemy, the railroad man, who will some day split their trunks for ties and burn their branches for fuel; and the forests of yellow pine, like those of the redwood and white pine, will be gone from the face of the earth. 
reent times. Between the rugged rock-masses are level spaces dotted over with bunch grass, sage (Arlemisia), and Linnsyris.

The geological substructure consists of a series of Tertiary beds of varions kinds, sedimentary volcanic ash, washed down from the highlands, and diatomaceons earth, interstratified with sheets of basalt. It is evident that this belt was for a long time, either wholly or in part, occupied by lakes. During long periods of quiet, all forms of life were abundant: the land supported a viried growth of arborescent and herbaceons plants, which furnished food to a great rariety of animals, while the watel was inlialited by fishes and mollusks of many kinds. At intervals, however, showers of ashes, mostly emanating from the volcanic rents of the Cascade Mountains, covered the conn. tay, destroyed, over large areas, all forms of animal and regetable life, and washing into the lakes, formed strata many feet in thickness. At other times, floods of lava poured down into this valley, spreading over the land and the lake-bottoms, to be covered again in time with other sheets of stratified tufus, or by fresh-water fossiliferous beds.

The Columbia, Suake River, John Day's River, the Des Chutes, and many minor streans, cut deeply into this plain. and expose in their banks sections of the beds described. In the ralley of the Des Chutes, cliffs 1,000 feet in height are formed of them; and alout the Dalles, the remains of horizon. tal 'Tertiary beds are seen 2,000 feet above the present level of the Columbia. These show that the lofty and continuous chnin of the Cascades formed a mighty dam, which kept back the drainage of the interior so that it formed a series of great lakes, bounded on the east by the Rocky Monistains, and on the west by the Cascades, and separated into several basins by the Blue Mountains und others of the desert runges.

'The accunulated water found an ontlet to the sea through the lowest gaps in the Cascade Mountains. Of these. the most im. portant was that where the gorge of the Columbia is now sitn. ated; others exist further sonth and are now trarersed by the the Klamath and Pit River (Sacramento). In the Columbia basin, the old lakes are all drained, or filled, and their bottoms are deeply scored by the draining streams. The lake of the Klamath basin is now represented by the Klamath Lakes, Rhett Lake, 
Wright Lake, Goose Lake, etc., which occupy the points of greatest depression.

Though much of this great plain has the aspect of a desert, only a small portion of it is absolutely sterile. 'There is much prairie land covered with a cont nuous sheet of grass; and even the more sandy and rocky surfaces have proved to be fairly good grazing ground. It is also true that the attempts to cultivate the soil have been attended with unexpected success, and about Walla-walla, that which was supposed to be a descrt surface is producing great crops of wheat.

\section{The Cascade Mountains}

Although represented on most maps as an unbroken line of elevation stretching with an almost north and south conrse from the Californian to the British line, with its hachures looking like an enormously long hairy caterpillar, no just conception is thus given of this broad and compound monntain belt. It is continuous with the Sierra Nevada of California ; and it would have been better if they had been designated by a common name. 'The mountain belt is in Oregon and Washington from thirty to fifty miles in width, consisting of a number of parallel ranges of which the highest is along its eastern border. This is crowned by a series of rolcanic cones, Mt. Shasta, Mt. Pitt. Mlt. McLaughlin, Mt. Jefferson, Mt. Hood, Mt. Adams. Mt. Rainier (Tacoma), and Mt. Baker, which range from 10,000 to orer 14,000 feet in height, are all capped with perpetual snow. and form the most impressive group of nountains on the continent. From the California line northward, the material of which these mountain ranges are composed is mainly eruptive in character. 'I'he peaks mentioned, and many others, are volcanic vents of which the fires are not yet extinct, and some of them have been in active eruption within a few hundred years. Like the Sierra Nevada, this great fold in the earth's crust was formed after the Triassic and Jurassic, but previous to the Cretaceous age; and yet, like all other great mountain belts, it has been formed by many additions made at rarious times. In California, the range is largely composed of granite and other crystalline rocks of ancient date, flanked by slates which have been proved by the California geologists to be of Triassic and Jurassic age; while the 
Cretuceous is deposited nncouformably upon these, rising to the height of but a few hundred feet above the sea. North of the California line, the rocks forming the mountains, as has been mentioned, are almost entirely eruptire; and it is evident that this has been the theatre of more violent volcanic action than any other part of the continent known to us. Most of the eruptions took place in 'Tertia'y times, as we know from the intercalation of the trap orerflows with the Tertiary lake-sediments, many of which are store-houses of regetable and animal fossils ; but they hare continued down to the present day.

Many years ago, when connected with Western Government Surveys, I followed these mountains from the California line to the Columbia, and at several points crossed lava streams which had flowed down the east flank of the Cascades, and were as fresh and ragged as the modern lava streams of Vesuvius. Not a particle of vegetation hal attached itself to then, and it is certain that not a hundred years have passed since some of them were flowing.

\section{Axcient Glaciers of the Cascade Mountaiss.}

As has been stated, the Rocky Mountains, from New Mexico to British Columbia, abound in evidences of ancient glaciation. This is also true of the Uinta Mountains, the Wasateh, the Sierra Nevada and the Cascade Mountains.

In the group of fire snowy peaks, called in Oregon the Three Sisters-because only three are visible from the Willamette Valley-miniatnre glaciers were found by our party in 1855 at the heads of McKenzie's Fork, and of one of the tributaries of the Dess Chutes; and ou Mt. Rainier a dozen or more have been described, some many miles in length. But all the glaciers and snow-fields now existing on the Cascade Mountains are utterly insignificane conplared with those of the glacial period. 'Then every gorge was filled with snow and ice, the broader and more irregular summits were covered with glaciers, and these descended several thousand feet below the present line of perpetual snow. Now we find, over miles square, the rock-surfaces planed smooth or grooved like a plowed field, and every projecting crest of roleanic rock, rough and ragged as it was, is rounded over and worn into 
a roche moutonnée. From the 'Three Sister's the glaciers descended into the valley of the Willamette on the west and that of the Des Chutes on the east; and I traced with the barometer the glacial nuarkings, from the snow-line to a point 2500 feet lower, where they pass under the allurium of McKenzic's Fork.*

\section{'The Forests of the Cascade Molntains.}

All the summits and western slopes of the Cascade Mountains are covered with a dense forest, mainly of evergreens, of which many of the trees are of gigantic dimensions. On the eastern slopes, the prairies in places run up the mountain sides, but the timber follows all the valleys down to the plain. East of the mountains are scattered trees of the yellow pine (Pinus ponderosa) and the western cedar (Juniperus occidentalis), and in some localities, as has been mentioned, groves and forests of the former. 'The evergreens which cover the mountains consist of four species of pine, viz., Pinus Lambertiana, P. monticola, P. albi.

* It has been claimed by Lecoq (Les Glaciers et les Climats), and following him, by Prof. Whitney and others (Later Climatic Changes), that the great development of glaciers during the Ice Period, such as those of the Canadian highlands, the Rocky Mountains and the Cascades, of which we have such abundant evidence, was not the effect of a cold period, but a warm one, which increased the precipitation and consequently the snow-fall, at all places where the temperature was low enough to cause it to take the form of snow. If this was all, however, the most extensive glaciers should be in the Alpine districts of the tropics or of the temperate zones, wherever the precipitation is most abundant and the temperature low enough to produce perpetual snow. But we have, on the summits of the Cascades, a demonstration of the fallacy of this view ; since here some of the mountains rise 14,000 feet and the line of perpetual snow is not over 7,000 feet, while the annual precipitation is greater than in almost any other portion of our country. In fact the snow accumulates in such quantity that. even in midsummer, it reaches so low that it is met and opposed by a vigorous forest growth, the product of a mild climate. It is evident that no elevation of temperature, though it should increase the evaporation on the Pacific and the rainfall on the coast, wonld cause the renewal of the ancient glaciers ; but with a depression of temperature which should continue the present winter conditions through the year, the precipitation remaining the same, the accumulation would soon cover the mountain summits with snow and 'ice and bring the glaciers down to their old limit. 
crulis and $P$. conturtu. Of these, the first is the most gigantic spectes of the genus. attaining in its chosen habitat in this range of mountains, a height of 300 feet and a diameter of from 12 tu 15 feet. P. monticola is much smaller, hardly equalling in dimensions its eastern representative, the white pine, but closely resembling it in general habit and ninor botanical characters. On the mountains it is less abundant than in the valley of Clark's Fork, but attains somewhat larger size. This, with the sugar pine and white pine, constitnte a well-defined sub-genus, characterized by five-leaved and blue-green foliage; fusiform, resinous, imbricated cones, hanging on the ends of a few large and high branches; and in the character of the wood. Three firs, designating by that name those bearing erect cones with permanent axes and deciduuus scales, are also common, viz., Abies grandis, A. nobilis, and A. amabilis. Of these, the first is the western balsam-fir, resembling our eastern balsam, but a moro magnificent tree, attuining an altitude of 300 feet. The last two are remarkable for the nagnitude of their cones, which are six inches in length and two and a half in dianeter, the first decorated with reflexed and fimbriated bracts, the second purple in color and dotted over with resin. Four spruces, Douglas's, Menzies's, Patton's, and the hemlock, are there. Of these, the first is the largest and the most abundant, attaining an altitude of over 300 feet and a diameter of 10 feet ; Menzies's spruce (Abies Silchensis) grows to a height of over 200 feet, and is generally as strict as a church spire; the hemlock is comparatively rare on the high lands, and is only seen at its best in the ralleys; Patton's spruce (Abies Pattoniana) is a near relutive of the hemlock, having the same feathery foliage, but that which is denser and richer. On the whole, it is in my judgment the handsomest of all the conifers. On some of the Alpine meadows among tho snow mountains-especially the Three Sisters-are scattered individual trees or groups of two or three kinds of fir and spruce, which surpass in symmetry and graceful grouping any human achievement in the way of landscape gardening. Where the fir forests are most dense, the trees are so thickly set that two great trunks may generally be reached by the extended arms. No undergrowth occupies the gromnd, and the folinge of the firs is confined to the higher branches, which interlock to make a roof 
impenetrable by the sun's rays. Sometimes the gloom of these forests is further enhanced by gray or black lichens, which drape the trunks and hang from the dead branches like the Spanish moss, but producing a far more funereal effect. Where fire has run through these forests, the trees, killed but not consumed, and subsequently overthrown by the wind, form a labyrinth through which it is sometimes well-nigh impossible to force one's way. The ground thus open to the sunshine is soon covered by a dense growth of bracken (Pteris aquilina), which often reaches a height of from six to eight feet. After this or with it, comes Ceanothus or manzanita, with huckleberries and serviceberries, which fruit so abundantly as even to tint the mountain sides with the black, purple or blue of their berries.

The larch, to which reference has already been made, is scattered sparsely over the eastern slope of the Cascades, and it here attains its maximum dimensions. The trunk is sometimes 200 feet in height, the branches relatively small, and the foliage fine and delicate in color, so that the larger trees look like lofty columns wreathed and decorated by climbing vines.

The hard-wood trees are few and insignificant as compared with the conifers. In the gorges and along the streams are the narrow-leaved and trembling poplars, and on the uplands the large-leaved maple and chinquapin (Acer macrophyllum and Castanopsis chrysophylla); the first is the only real tree-maple of the west coast. It attains a height of $\% 5$ to 80 feet, and the leaves, averaging six inches in diameter, on young plants are sometimes many times as large. The chinquapin, though usually a shrub, occasionally forms a handsome tree 30 to 50 feet in height, conspicuous for the contrast between the bright green of the upper and the golden yellow of the under surface of its leaves.

\section{'The Gorge of the Columbia.}

This is one of the most impressive and interesting topographical features in all the picturesque West. It is cut with a nearly straight westerly course, across the whole breadth of the Cascade Mountains, fifty miles, and its banks rise from 2,000 to 4,000 feet directly from the river side. Must of the material of which the walls are composed is basalt. 'This can be seen to form dis- 
tinct layers, the products of different averflows from the gresut voleanic vents north and sonth of it. Cape Horn, $a$ bold head. land, shows a rertical face of trap nearly 500 feet in height.

No one who examines the gorge of the Columbia will fuil m be convineed that it has been cut by the river. 'I he general altitude of the mountains, in which there are no other passess lower than about 5,000 feet, as well as the altitude of the lake deposits on the eastern side, indicate that the work of cutring this chanmel began at a height of not less than 3,000 feet above the sea. At this time the river must have had a fall of at least this number of feet into the ralley of the Willamette, and we must picture to ourselves a series of rascades of greater magnitude and more picturesque than any now known. 'This waterpower was, however, busily engaged in cutting down the lanrier; and in process of time this was so completely removed that navigable canal was opened from the Dalles to the ocean. 'The western entrance to the gorge is unw at tide-level, and the lower part of the river is, like the Hudson, an arm of the sen. It is true that at present the "Cascades of the Columbia" form a ee. rious interruption to the navigation of the river, for they are produced by a dam 63 feet high, which fills the channel for three miles. But this dam. as we know, is of recent date, and has been caused by an aralanche from the sides of the gorge. Above it, the river is simply a long lake, and in low water a series of stumps and trunks can be seen coming up from below the water. level, which belonged to trees that could never have grown in the places they occupy, if the barrier of the Cascades had existed.

Steamboats navigate the Columbia from the Dalles down, with a transfer at the Cascades; and this is much the hetter ronte to take for those who would get a good view of the gorge, with its imposing walls, its hanging forests and its picturesque waterfalls which leap 1,000 feet from the cliffs, - to say nothing of the old Indian burial-grove, and the multitude of silicified tree trunks at the Cascades. The railroad is built along the face of the sonth. ern cliff, high above the water, and although it gives only a onesided view of the gorge, is generally chosen by travelers who pre. fer rapid transit to beanty of scenery. 


\section{The Lower Columbia.}

The country bordering the Lower Columbia is too well-known to require detailed description. I am compelled, however, to refer to one or two points in its physical structure, which are of special interest when brought into connection with facts of similar import observed in the region about Puget's Sound. I have said that the Lower Columbia is an ar'm of the sea. It is in fact a deep river valley which has been flooded by an influx of the sea caused by subsidence. This brings the tide-water to the foot of the falls of the Willamette at Oregon City, and to the Cascades. It requires no argument to prove that such a channel could not have been cut unless by a rapid stream flowing into the ocean when it stood at a lower level. Whether the change in the relative level of land and sea here remarked was part of a general morement that produced the influx of the sea into the fiords which fringe the northern coast; and whether this is nbt a part of a still grander movement that flooded the old excarated valleys of the James River, the Potomac, the Schuylkill, the Hudson, the St. Lawrence and the Siguenay, and at the same time filled the fiords of the northeastern coast, are questions which cannot now be fully answered, but are worth considering.

It will be noticed that the general plan of the topography of this part of the coast is altogether similar to that of California ; namely, the great wall of the Cascades, bordered on the west by the Willamette and Cowlitz valleys and the Coast Mountains, are re-produced further south by the Sierra Nerada, the great California valley, and the Coast Ranges; and their topographical features are not only physically similar, but are geologically identical, - the Cascades being the northern continuation of the Sieria Nerada, the rnore modern Coast Mountains following continuously the coast line; the great trough between them being essentially one, but filled, in its centre, by a mass of mountains.

'The forests of the country bordering the lower Columbia are a pliysical feature that will strike every trareler with surprise and admiration. They are also of primary importance economically, since they form the basis of the most important industry of the northwest coast. 'They are mostly composed of evergreen trees which attain an altitude of 200 to $300 \mathrm{feet}$, and are crowded 
so closely that when an oproning is made in the forest it seems strrounded by a wall of limber. These great foresis strefch from the Californian to the British line on the summits and eastrom flank of the Cascades, over ull the Coust Monntains, and in the lowlands aloug the Willamette and the Cowlitz. and about l'uget's Sound, with the exception of prairies that form part of the surface of the Willancete valley, and oceupy limited areas about the sound.

In sonthwestern Oregun and northern California are the famous redwond groves, the only place in the world where this magniti. cent tree (Sequoin sempervirens) grows in such numbers as to form forests. It extends in clumps and scattered trees fur down the coast in California, and it does not reach the Columbia on the north, so that its range is quite restricted. About Port Orford and Humboldt Bay it is the principal timber tree, and in size it almost equals its gigantic relative, the inammoth tree of Calaveras County (Sequoiu giganteu).*

At Port Orford one may see hundreds of redwood trees of which the trunks attain a diameter of 10 to 15 feet; but as the lumber and timber they furmish is of excellent quality. they are being destroyed at a rate that will soon exhaust the supply.

Along the Colmmbia and abont Puget's Sound the principal trees are the Douglas and Menzies spruces, the bilsam tir, the western arbor vita and the hemlock. In some localities, especially further north, two cypresses are abundant, the Nootka cypress (Chamcecyparis Nutkuensis) and the ginger pine (C'. Larosoniana). The latter is sometimes culled the ginger pine from the fragrance of its wood. It is cultivated for its beanty and esteemed for the excellence of its lumber. Much less mumerous, but widely scattered, is the western yew (Tuxus brerifolia). often a handsome tree 50 to 60 feet in height. Along the river

* Great scientific interest attaches to these two species of Siquoia, since they are the only representatives of the genus now living on the earih's sur. fuce, and are a relic of the grand forests which in Tertiary times covered all the northern part of this continent, and in which they were associated with other species of Sequoia, and with a multitude of other evergreen and decid. uous trees, most of which have disappeared, but a few remain, - the tulip tree, deciduous cypress, magnolias, etc., - which form the glory of our pres. ent forests. 
sides are many cottonwoods (Populus trichocarpa), the Oregon ash (Fraxinus Oregona), and an arborescent alder (Alnus rhombifolia), which reaches an altitude of 60 feet, with a trunk-diameter of 12 to 15 inches. On the dryer and higher ground is found Pinus ponderosa, and on the lower, thickets of P. contorta, often growing like canes in a cane-brake. Scattered through this lowland forest are also the two arborescent maples of the west, Acer macrophyllum and A. circinnatum. Of these the latter, called the vine maple, is a peculiar feature in the forests of the Lower Columbia, Puget's Sound, and Vancouver's Island. It is rarely more than six inches in diameter, the trunks very slender, and several springing from the same root. These droop, and reaching the ground, frequently take root at the summit. Where these interlacing trunks are numerous, they form a thicket which is almost impenetrable. 'To this meagre list of angiospermous trees, I should add Garry's oak and the Madroñ (Quercus Garryana, and Arbutus Menziesii). The oak, scattered about the open grounds of the Willamette Valley and Puget's Sound, occasionally attains a diameter of three or four feet, but with a spreading and irregular growth and brittle wood, so that it has little value as a timber tree. The "Madroña" is a small tree, but much admired for the beauty of its foliage, and the peculiarity of its bark. 'The former is persistent and rich, and the latter exfoliates in brown and greenish layers of different shades.

The undergrowth of the Pacific coast forest, where the latter is not tou dense, is abundant and varied. Over the rocks and fallen tree-trunks is a thick mat of mosses, which grow with a luxuriance and exhibit a variety nowhere rivalled in the eastern States. Ferns are less numerous than might be expected in this moist climate, but a few species are abundant and grow with great luxuriance. The most commion is the cosmopolitan bracken (Pteris aquilina), the next, Aspidium munitum, strikingly like our eastern $A$. acrostichoides, but having a much stronger growth. Of the less numerous species, a respectable list could be made, but on the whole the ferns are not an important element in vegetation. Of the under-shrubs, the most striking is Fatsia horrida; this has the aspect of an Aralia; it has a thick woody stem six to ten feet long, somewhat decumbent at base, but bearing above a number of large palmate leaves. Both stem 
and leares are very prickly, and it is a common but probably un. grounded belief that its spines are highly poisonous. A larere shrubloy äpirae (S. Duuglasii) grows six to ten fect in height, with numerous large open panicles of inconspicuons flowers. Several species of C'eanothus abound, the most common heing C. velutinus, which forms dense thickets. Lonicera incolucrata, conspicuous from its black belladonnelike fruit, survound. ed by large persistent purple involncres, is found along the streams, with one of the most showy of all the Oregon shrubs, Cornus Nuttullii, Audubon, the western representative of onr dogwoorl. Usually it is sinaller, but occassioually becomes a tree 50 feet in height. 'The flower-like calyces are large, white, and less crumpled than those of the eastern trec.

More interesting than these to botanists, as well as to the genleral public, are the fruit-bearing shrubs, the ".Sillal," (limullherin shallon,) the Oregon grape (Berberis agnifolimm and B. pinnula). and the "salmon-berry," (Rubus spectubilis). Of these, the first covers the ground over great areas with its creeping or decumbent stem, its broad, oval, shining leaves, and its pendent, lack and edible fruit. The two species of Berberis, so well known under their old name, Mahonir, are low shrulss, with jinnate, spiny leaves, yellow, clustered flowers and blue bloomcorered acid berries. 'They are not unfrequently cultirated as ornamental plants in the eastern States. 'The salmon-bery takes its name from the color of the fruit, which resembles that of the flesh of the salmon. It is a tall, strong-growing raspberry, with conspicuous purple flowers and large ovoid fruit, much esteemed by the Indians, but rather insipid. Rubus Nuthanus, the white variety of om flowering raspbery, is everywhere common, with the precise habit of its castern representative.

\section{Surface Gelogy of the Plikt's Solxin Basix.}

'The name Puget's Sound is, in popular use, made to cover all the peculiar group of inlets and tideways which lie immediately east of Vancourer's Island,-P'uget's Sound proper, Almiralty Inlet, Hood's Canal, etc. 'These oceupy the northern extension of the great Columbian valley, which, like its eounterpart in California, lies betwên the Coast, ranges and the Cordillerus. Further north still, this depression is deflected toward the nortl. 
west by a change in the direction of the Cascade? Mountains, and of the representatives of the Coast ranges on Vanconver's Island, is mostly occupied by water, and is known as the Gulf of Georgia. In Washington Territory the Coast Mountains are higher than in Oregon, and have received the local name of ;the Olympian range, of which the highest summit is called Mt. Olympus. 'Ihis range terminates somewhat abruptly, but is apparently continued in the mountains of Vancouver's Island. 'Through the gap' between these and the Olympian range a deep channel is cut, now an arm of the sea, called the Strait of Juan de Fuca. In former times, when this portion of the continent, and probably the whole northwest coast, stood higher above the ocean, this strait was the ralley of a great river, which drained most of the western slope of the Cascades in Washington 'Territory, and had as branches the Skagit, Snoqualme, Dwanish, Puyallop, Nisqually and various minor streams. During the ice period, this hydrographic basin was filled with a great glacier made up of contributions from all the surrounding mountains. It flowed out to sea by the Strait of Fuca; but this channel was far too narrow for it, and it spread all over the southern portion of Vancouver's Island, planing off, rounding over or deeply scoring the rocks in its passage, and leaving its autograph so plainly written that he who runs may read.

As the glaciers retreated, they left behind a sheet of drift several hundred feet in thickness, - partly waterworn and stratified, partly unstratified boulder clay with striated pebbles. 'These drift deposits formed a plain of which the surface was nearly level. In process of time, the draining streams had cut in this plain a series of valleys all tributary to one which led out through the Strait of Fuea to the ocean. After perhaps some thousands of years, during which the excavation of these valleys progressed, a subsidence of the land or rise of the water-level caused the sea to flow in and occupy the main valley and all its tributaries up to the base of the mountain slopes. Such in few words is the history of the formation of this remarkable system of inlets. 'They are simply the flooded valleys of a great river and of the branches which formerly joined it, but which now empty into the extremities of the finger like inlets that have partially replaced them. 
There are but few localities in the l'uget's Sonnd basin where the rocky substratum rises so as to be visible ubove the water. level. Along the northern and western maregin of Vancouver ${ }^{\circ}$, Sucia, Oreas and Whidby Islands, and at (:huckerunts and Sin. liorne the rock appears, but at 'Tacomat, Steilacom, Seatte. Port Madison, Port 'Townsend, and it may be said generally abont the round, the shores are steep bluffs, 100 to lio feet in height. composed of drift alon: From the cliffs ar. Port lichmond and 'T'acomil, I took sub-ingular scratched and ice-worn pebbles, as characteristic and convincing as any to ba fonnd in the bonleler elaty of the eastern states.

'The subsidence which caused the sealvatep to flow into the subatrial excavated valleys of ['nget's Sound, filled ulso the chasnnel of the Columbia to the Cascades, and the system of fiords that fringe the northwest coast, of which these are repre-entitives.

We hare evidence, too, that the area ocenpied by the sea was at one time much more extensive than now, for all the comntry inmediately about Puget's Sound is marked with a series of marine terraces which Mr. Bailey Willis, who studied them when connected with the 'Transcontinental Surrey unler Prof. Pumpelly. tells me can be traced to a height of 1,600 feet above the present occun level. These terraces are conspicnons on the low divide which separates the valley of the Cowlity from the basin of Pn. get's Sound; and here, as over much of this region, the ground is covered with pebbles and waterworn boulders, the product of the long.continned dash of the shore wares on a slope composed of drift materials. In the advance aud recession of the shore. line, the finer materials have been mostly washed away, and the stony surface has little agricultural value. Fortunately it is well adapted to the growth of trees; and the splendid forest which corers it is perhaps an equivalent for all it has lost. The facts here given show why the cultivation of the soil in Washington 'Territory is limited to the narrow belts of moderu alluvium along the streams, and indicate that the fisheries, conl-mining, and lumber industry must be in the future, as they are now, the most important sources of wealth. 


\section{Geological Substructere.}

The sheet of drift which has been described eovers most of the lowland, and conceals the underlying rocks so that they appear ouly about the margin of the basin. 'The foot-hills of the Sierra, like the more elevated portions, are composed chiefiy of eruptive rocks ; but at various places along the northern and eastern margin of the basin, the drainage streams have exposed sedimentary strata. 'I'hese are all Cretaceons or 'T'ertiary. On Queen Charlotte's Island, as we learn from the Canadian geologists, are Lower Cretuceous rocks, very much disturbed, but containing beds of lignite converted into anthracite, and many mollusks which apparently represent the Neocomian of the Old World.

On Vancourer's Island, the granites and old metamorphic sediments are succeded by Upper (Yretacenus strata, which contain sereral valuable seams of coal that have been worked for many years. Specimens of the fossil plants and mollusks associated with these beds, were sent by Mr. George Gibls to the writer in 1858. Among the former were Inoceramus, and Baculites, which gave the earliest information of the Cretaceous age of these deposits. Descriptions of some of the fossil plants were published by the writer in the Proceedings of the Boston Society of Natural History for 1863. On Oreas and Sucia Islands are also exposures of Cretaceous rocks which abound in fossils.

On the east side of the basin, coal outerops at sereral points, and has been worked at Bellingham Bay on the Skagit River, at Newcastle, Carbonado and Wilkinson. At Carbonado the coalbearing rocks, turned up at a high angle, are cut across in a cañon formed by Carbon River, and a very satisfactory view is here obtained of the structure of one of the local basins. The series is several thousand feet in thickness; and in this section nine workable seams of coal are exposed. At Wilkinson and in that vicinity, Mr. Willis made a careful exploration of another basin, which also includes several beds of coal and some thous. ands of feet of associated rocks. From these localities and others further north, large collections of fossil plants have been made by the writer and his assistant, Mr. Edward Lorrarce. These represent a rich and interesting flora of Upper Cretaceous and 
'Tertiary ages, of which figures and descriptions will be published by the U. S. Geological Survey.

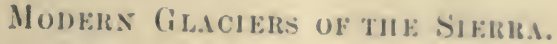

From the IIillamette Valley and Puget's Sumd, splendid views are obtained of the great snow-peaks of the Cascade Mount. ains, - the 'T'lnee Sisters, Mt. Jefferson, Mt. IIood. Mt. Adams, Mt. St. Helens, Mt. 'Iacoma and Mt. Baker. Of these. Mt. Hood has an altitude of 11,225 feet, Mt. A1:ums 12,250, and Mt. 'T'acoma 14,400. In Colorado and California are a number of summits of equal absolute lieight, but they have nothing like the relief above their suroundings that these hare, carry fur less jerpetual snow, and are in erery way less impressive. In Washton 'Territory, the permanent snow-line on the west side of the mountains is about 6,500 feet, on the cast side several hundred feet higher. Mt. 'Tacoma carries, therefore, alont 8,000 foet of snow. Below this it is covered with a dense furest. Its foot. hills nowhere rise to the height of 2,000 feet above the sea, and hence are invisible at a distance; so from many places about the Sound, practically the whole of the mountain is seen in one view,-a gigantic cone 14,000 feet in height, apparently rising directly from the sea-level! Mt. Shastat has the same altitude, and as seen from Scott's or Strawbery Valley, is wonderfully impressire; but it is situated further iuland and further south. its base is higher and it has less snow, and it is therefore some. what less impusing. Mt. Hood, as secu nuder farorable circumstances from Fort Vancourer, especially when reflected from the lake-like surface of the Columbia, is as beantiful but fal less, grand. It is not too much to say then, that no other mountain on this continent, and none in Europe, rirals in grandeur and beaty Mt. 'Tacoma; and it is doubtful whether in the world there is any that produces a groater impression upon the beholder.

'l'hough appearing in the distance so symmetrical and smooth, Mt. 'Tacoma lias been found to be a ragged and compound mass consisting of three conspicuous summits, and many subordiunte peaks, with preeipices of 2,000 to 3,000 feet in height, and decp groreses which make the ascent dithieult and even dangerous, It 
has been ascended, however, screral times, and its labyrinths sufficiently explored to prove that it carries from eight to twelve glaciers, some of which are many miles in length and will bear comparison with those of the Alps.

Every traveller who enters the Puget's Sound region from the south, is sure to be struck by the turbid, milky appearance of the water of the Cowlitz River, along which the railroad runs for miles. 'This character it shares with all streams which drain glaciers. and has caused the Swiss mountaineers to give to the water of such streams the mame of " (iletscher Mileh." This turbidity is due to the sediment produced by the constant grinding action of these enormous masses of moring ice, set with stones, upon their beds, and attests the sometimes disputed efficiency of glaciers as eroding agents. 'The Puyallop, White River, and other streams which come down from Ml t. Tacoma, are allike milky, and each shows that one or more glaciers are contintrally grinding away at its head. On the contrary, the streams which do not come from glaciers and are supplied by rain only and that filtered through the decaying vegetation of the dense forests, carry very little sediment, and that chiefly carbonacenus matter. These are clear but brown, and the contrast which the water of such streams presents to that of the rivers which drain the glitciers, is very striking, justifying the wames borne by two such, of Black and White Rivers.

It has been contended by some writers. as before mentioned, that the extension of glaciers in former times was due simply to an increase in the amount of precipitated moisture; but it is easy to see that the heavy rainfall of Washington Territory might be increased indefinitely with no considerable elongation of the glaciers. But even with the rainfall remaining as it is, if a depression of temperature should take place, carrying the present conditions of winter through the year, the glaciers would soon creep down into their old beds, fill all the valleys of their draining streams, and finally coalesce to form one grand glacier which would flow out through the Strait of Fuca to the ocean.

Following the coast northward from Puget Sound, we find the glaciers coming down lower and lower, until in Alaska they reach the sea-level. No one can claim that this is because the precipitation is greater there, since observations show that it is 
not; but the careful observer must surely recognise that it is because at the north the temperature is lower. He must also aceept these facts as a demonstration that the prime faclor in the production of the phenomenu of the lee Period, was a seculur alepression of temperature: that it was a period of cold and not of warmtl. 
$2-O D-43-8-2$ 


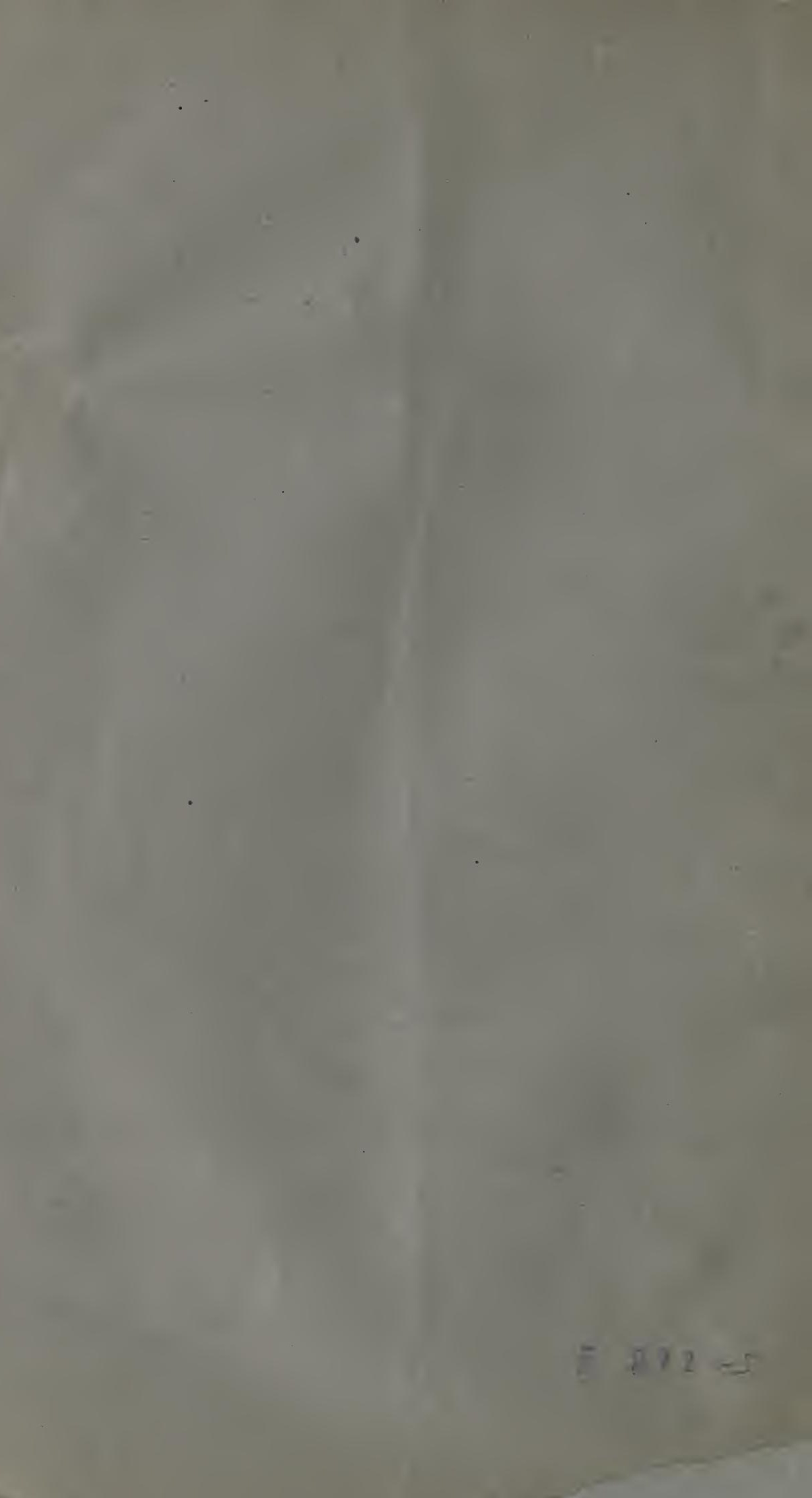




